\title{
Development of a Validated Stability Indicating Liquid Chromatographic Method for the Determination of Pterostilbene
}

\author{
Mukthinuthalapati Mathrusri Annapurna*, Bukkapatnam Venkatesh, Gunnam Ravi Teja \\ Department of Pharmaceutical Analysis and Quality Assurance, GITAM Institute of Pharmacy, GITAM University, \\ Visakhapatnam-530045, Andhra Pradesh, INDIA.
}

\begin{abstract}
Introduction: Pterostilbene, a stilbenoid possess diversified pharmacological activities. In the present study, a stability-indicating liquid chromatographic method was proposed for the determination of Pterostilbene in pharmaceutically available formulations. Materials and Methods: The chromatographic separation was achieved on Phenomenex C8 type column as stationary phase. UV detection was carried out at $219 \mathrm{~nm}$. Pterostilbene was subjected to various stress conditions such as acidic, alkaline, oxidative, thermal and photolytic degradations. Results:The drug was found to be sensitive towards acidic and alkaline stress conditions. The proposed method was validated as per the $\mathrm{ICH}$ guidelines and successfully applied to the available marketed formulations. Conclusion: The proposed method is selective, specific, robust and can be applied for the assay of pharmaceutical dosage forms.
\end{abstract}

Key words: Pterostilbene, Stability-Indicating, RP-HPLC, Validation, ICH guidelines.

\section{INTRODUCTION}

Pterostilbene (PTB), was first isolated from Pterocarpus santalinus (red sandalwood), ${ }^{1}$ and is an active constituent in Pterocarpus marsupium..$^{2-5}$ It is traditionally used as the medicine in the therapy of diabetes. It has also shown diversified pharmacological activities: anti hyper-glycemic; ${ }^{6}$ hypolididemic; ${ }^{7}$ anti-cancer; ${ }^{8-10}$ anti-diabetic ${ }^{11-13}$ and antifungal ${ }^{14}$ properties. PTB, a methyl ether of resveratrol, which is chemically 3,5-dimethoxy-4'- hydroxy-trans-stilbene $\left(\mathrm{C}_{16} \mathrm{H}_{16} \mathrm{O}_{3}\right)$; Mol. Wt. - $256.296 \mathrm{~g} / \mathrm{mol}$ (Figure 1).

Only two liquid chromatographic methods have been developed for the determination of Pterostilbene, one with fluorescence detection ${ }^{15}$ and the other in rat plasma ${ }^{16}$ and also one spectrophotometric method. ${ }^{17}$ Till date from the literature available it is evident that no stability indicating liquid chromatographic method was available assay of Pterostilbene in formulations.

\section{MATERIALS AND METHODS}

\section{Instrumentation and Chromatographic Conditions}

The chromatographic separation was successfully achieved on - HPLC system: UFLC Shimadzu Prominence system (CBM-20Alite) model equipped with SPD M20A detector (PDA); Stationary Phase: Phenomenex C8 type column $(250 \mathrm{~mm} \times 4.6 \mathrm{~mm}$ i.d., $5 \mu \mathrm{m}$ particle size); Mobile Phase: $0.1 \%$ Trifluoroacetic acid (TFA) in water $(\mathrm{v} / \mathrm{v})$ : acetonitrile $(10: 90 \%, \mathrm{v} / \mathrm{v})$; Flow rate: $0.6 \mathrm{ml} / \mathrm{min}$; Injection volume: $20 \mu \mathrm{l}$; $\mathrm{UV}$ detection wavelength: $219 \mathrm{~nm}$; Temperature: Ambient $\left(25^{\circ} \mathrm{C}\right)$.

\section{Chemicals and Reagents}

Pterostilbene standard ( $>99.0 \%$ purity) was obtained from Oxford laboratory, India. It is available as capsules with brand names: PTEROSTILBENE (Source Naturals Inc. (Canada); Label claim: $50 \mathrm{mg}$ ), PTEROSTILBENE (Absorb Health (North Caro-
Submission Date: 28-11-2017 Revision Date: 24-01-2018, Accepted Date: 17-05-2018

DOI: 10.5530/ijper.52.4s.77 Correspondence: Prof. Mukthinuthalapati Mathrusri Annapurna, Department of Pharmaceutical Analysis and Quality Assurance, GITAM Institute of Pharmacy, GITAM University, Rushikonda Visakhapatnam, Andhra Pradesh-530045, INDIA Phone: $91-9985654603$ E-mail: mathrusri2000@ yahoo.com

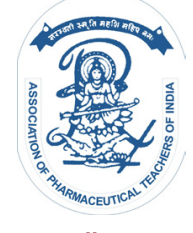

www.ijper.org 


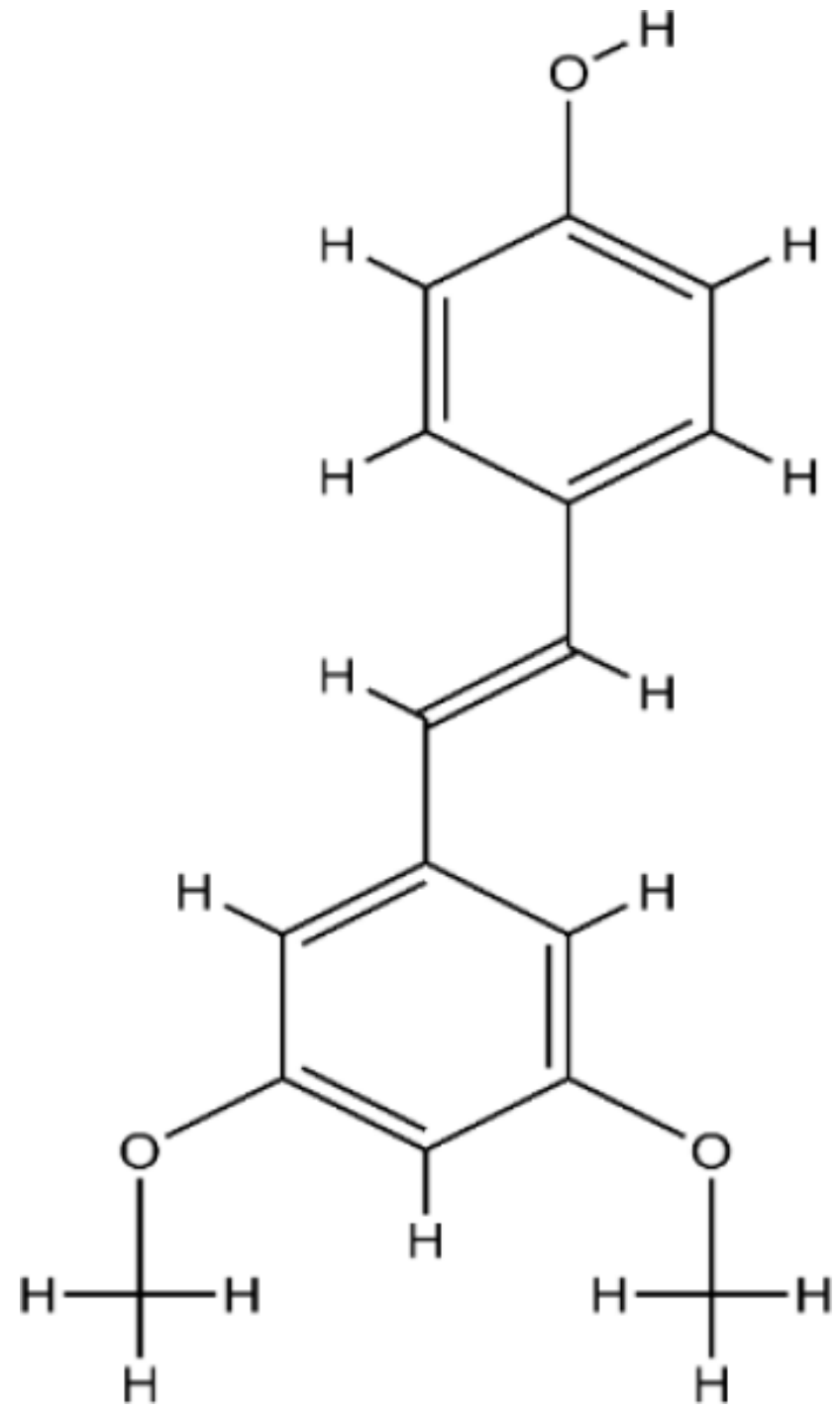

Figure 1: Structure of Pterostilbene.

lina); Label claim: $100 \mathrm{mg}$ ). Trifluoroacetic acid (TFA), Water, Methanol, Sodium hydroxide $(\mathrm{NaOH})$, Hydrochloric acid $(\mathrm{HCl})$ and Hydrogen peroxide $\left(\mathrm{H}_{2} \mathrm{O}_{2}\right)$ were purchased from Merck (India) and all chemicals are of HPLC grade and used as received.

\section{Preparation of $0.1 \%$ TFA Buffer (v/v)}

The mobile phase was prepared by accurately transferring $1 \mathrm{ml}$ of TFA in to a $1000 \mathrm{ml}$ volumetric flask and dissolved with HPLC grade water.

\section{Preparation of Stock Solution}

The stock solution was prepared by transferring accurately $25 \mathrm{mg}$ of PTB in to a $25 \mathrm{ml}$ volumetric flask and diluting with mobile phase $(1000 \mu \mathrm{g} / \mathrm{ml})$ and further dilutions were made on daily basis from the stock solution with mobile phase as per the requirement.

\section{Validation}

The developed method was validated as per ICH Q2(R1) guidelines, $2005 .{ }^{18}$ The linearity $(0.02-250 \mu \mathrm{g} / \mathrm{ml})$ and precision $(10,20$ and $50 \mu \mathrm{g} / \mathrm{ml})$ studies were conducted. The accuracy studies were accomplished with three pre-delineate spiked concentration levels $(80,100$ and $120 \%$ ). In robustness study the chromatographic conditions were marginally modified for: flow rate $(0.54$ and $0.66 \mathrm{ml} / \mathrm{min}) ; \%$ organic phase (88 and $92 \% \mathrm{v} / \mathrm{v}$ ) and detection wavelength (217 and $221 \mathrm{~nm})$. The robustness study was carried at a concentration level of $20 \mu \mathrm{g} / \mathrm{ml}$ of the standard. All the validation data obtained was taken in triplicate.

\section{Forced Degradation Studies}

To confirm that the analytical method is stability-indicating, PTB was exposed to stress under to various conditions to accomplish forced degradation studies. ${ }^{19}$ As the present $\mathrm{ICH}$ guidelines did not make any statement regarding the detailed degradation conditions in the stress testing, the presently used forced degradation conditions were all based on trial and error.

Acidic degradation was performed by refluxing stock solution $(1 \mathrm{ml})$ with $1 \mathrm{ml}$ of $1 \mathrm{~N} \mathrm{HCl}$ for a time of $60 \mathrm{~min}$ at $80^{\circ} \mathrm{C}$ in a thermostat, the solution was cooled, neutralized and then diluted as per requirement. Alkaline degradation was conducted by heating stock solution $(1 \mathrm{ml})$ along with $1 \mathrm{ml}$ of $1 \mathrm{~N} \mathrm{NaOH}$ for a period of $60 \mathrm{~min}$ at $80^{\circ} \mathrm{C}$, later it was cooled, neutralized and then diluted as per requirement. During oxidative degradation, stock solution $(1 \mathrm{ml})$ was left in a $10 \mathrm{ml}$ volumetric flask with $1.0 \mathrm{ml}$ of $30 \% \mathrm{H}_{2} \mathrm{O}_{2}$ for a period of $60 \mathrm{~min}$ at $40^{\circ} \mathrm{C}$, later cooled and then diluted. Thermal degradation was conducted by exposing a definite quantity of PTB standard in solid state and also in solution state to dry heat in a hot air oven maintained at $80{ }^{\circ} \mathrm{C}$ continuously for 7 days and the resultants were cooled and diluted before the study. For Photolytic degradation, the sample in solid state taken in a petri-plate and placed in a UV cabinet for the exposure to cool florescent and near UV lamp continuously for about 7 days. The sample was spread as a thin layer and sealed with a transparent cover to minimize the effects of the changes in the physical state. . The solution was prepared with acetonitrile and further dilution with diluent.

\section{Assay of Marketed Formulations}

Twenty capsules of each brand of PTB were procured from the local pharmacy store, weighed, crushed into fine powder and was extracted and filtered, from which 


\begin{tabular}{|c|c|c|c|c|}
\hline Mobile phase/Reagent & $\lambda(\mathrm{nm})$ & $\begin{array}{l}\text { Linearity } \\
(\mu \mathrm{g} / \mathrm{ml})\end{array}$ & Method & Reference \\
\hline Acetonitrile: water $(50: 50, \mathrm{v} / \mathrm{v})$ & $\begin{array}{l}\text { Excitation } 330 \\
\text { Emission } 374\end{array}$ & $5-100$ & HPLC & 15 \\
\hline Acetonitrile: $0.1 \%$ formic acid & 320 & $0.2-20$ & HPLC & 16 \\
\hline $0.1 \%$ TFA: Acetonitrile (10:90) & 219 & $0.02-250$ & $\begin{array}{c}\text { Stability indicating } \\
\text { RP-HPLC }\end{array}$ & Present work \\
\hline
\end{tabular}

the final dilutions were made as per the requirement prior analysis.

\section{RESULTS AND DISCUSSION}

\section{Method Development and Optimization}

An attempt has been made to develop a stability indicating RP-HPLC method for the assay of PTB in pharmaceutical products. From the literature, it was evident that only two chromatographic methods were available, which were summarized in comparative study given in Table 1 and compared with the present method. PTB in its UV spectrum (Figure 2), shows maximum absorbance at 219 and $307 \mathrm{~nm}$, but the degradations products formed were clearly detect only at $219 \mathrm{~nm}$, for which it was selected as the wavelength of detection. The drug samples were analyzed using different mobile phase compositions and flow rates. $0.1 \%$ TFA in water $(\mathrm{v} / \mathrm{v})$ is adopted as aqueous phase, as it suppresses the ionization of residual silinols present in the stationary phase and thereby facilitates sharp peaks with low tailing factor. Finally, a mixture of $0.1 \%$ TFA in water $(v / v)$ : acetonitrile $(10: 90 \%, \mathrm{v} / \mathrm{v})$ with a flow rate of $0.6 \mathrm{ml} /$ min has produced a desirable sharp peak with suitable system suitability parameters. The typical chromatograms of blank and PTB was shown in Figure 3a-3b respectively.

\section{Method Validation}

The method was validated for system suitability, linearity, limit of quantitation (LOQ), limit of detection (LOD), precision, accuracy, selectivity and robustness. ${ }^{18}$

\section{Linearity}

PTB shows linearity over a concentration range of $0.02-250 \mu \mathrm{g} / \mathrm{ml}$, with their percentage relative standard deviations (\%RSD) in limits (Table 2). The limit of quantitation (LOQ), limit of detection (LOD) were found to be 0.01965 and $0.00648 \mu \mathrm{g} / \mathrm{ml}$ respectively.

\section{Accuracy}

The method accuracy was demonstrated by the $\%$ recovery at three different concentrations i.e., 36, 40

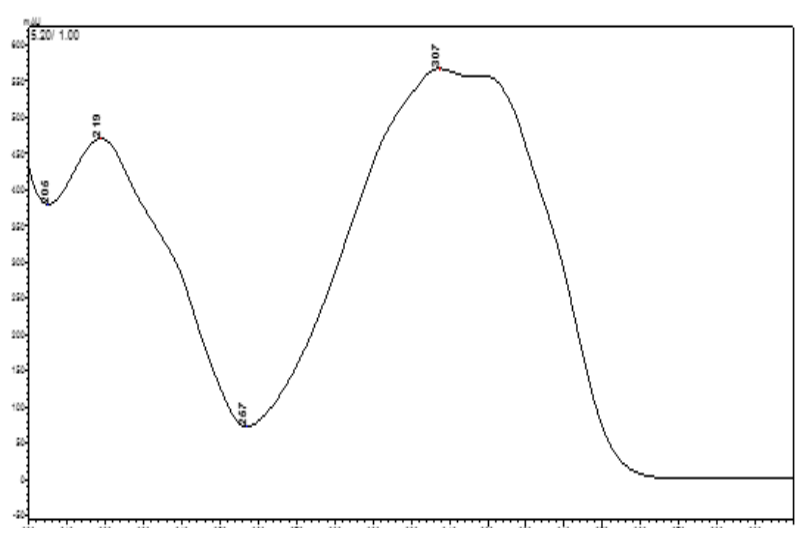

Figure 2: UV Spectrum of Pterostilbene.

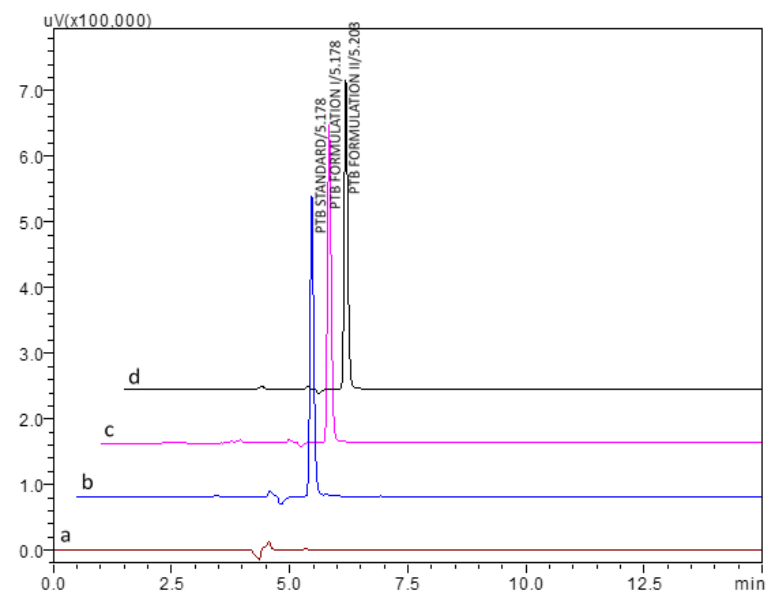

Figure 3: Typical Chromatograms of: (a) Blank; (b) Pterostilbene standard (20 $\mu \mathrm{g} / \mathrm{ml})$; (c) Formulation I $(20 \mu \mathrm{g} / \mathrm{ml})$ and (d) Formulation II $(20 \mu \mathrm{g} / \mathrm{ml})$

and $44 \mu \mathrm{g} / \mathrm{ml}$ (80, 100 and 120\%), in which the known amount of standard was spiked to the samples. The $\%$ recovery was found to be $98.91-99.59 \%$ and $\%$ RSD in limit with and very low standard error mean (SEM).

\section{Precision}

Precision studies were conducted at three concentrations i.e., $10,20,50 \mu \mathrm{g} / \mathrm{ml}$ for both intra-day and inter-day precision for which the $\%$ RSD was found to be 0.02 $0.67 \%$ (Table 3).

\section{Robustness}




\begin{tabular}{|c|c|c|}
\hline \multicolumn{3}{|c|}{ Table 2: Linearity of Pterostilbene. } \\
\hline Concentration $(\boldsymbol{\mu g} / \mathbf{m l})$ & *Mean Peak Area \pm SD & RSD (\%) \\
\hline 0.02 & $3425 \pm 10.96$ & 0.32 \\
\hline 0.5 & $85138 \pm 127.71$ & 0.15 \\
\hline 1 & $170349.09 \pm 545.12$ & 0.32 \\
\hline 2 & $342598 \pm 1438.91$ & 0.42 \\
\hline 5 & $852099 \pm 937.31$ & 0.11 \\
\hline 10 & $1701798 \pm 1361.44$ & 0.38 \\
\hline 15 & $2577209 \pm 9793.39$ & 0.45 \\
\hline 20 & $3409584 \pm 15343.13$ & 0.37 \\
\hline 50 & $8513960 \pm 23839.09$ & 0.18 \\
\hline 100 & $17909796 \pm 66266.25$ & 0.63 \\
\hline 200 & $34095870 \pm 61372.57$ & \\
\hline 250 & $42618800 \pm 268498.44$ & \\
\hline Slope \pm SD & $: 175933.33 \pm 9199.66$ \\
\hline Intercept \pm SD & $: 42115.67 \pm 818.61$ \\
\hline & $: 0.9997$ \\
\hline (LOD) & $: 0.00648$ \\
\hline (LOQ) & $: 0.01965$ \\
\hline Range) & $: 0.02-250$ \\
\hline
\end{tabular}

*Mean of three replicates

\begin{tabular}{|c|c|c|c|c|c|c|c|c|}
\hline \multirow[b]{2}{*}{ Concentration ( $\mu \mathrm{g} / \mathrm{ml})$} & \multicolumn{4}{|c|}{ Intra-day Precision } & \multicolumn{4}{|c|}{ Inter-day Precision } \\
\hline & \multicolumn{2}{|c|}{$\begin{array}{c}{ }^{*} \text { Measured } \\
\text { Concentration }(\mu \mathrm{g} / \mathrm{ml}) \quad \pm \\
\text { SD }\end{array}$} & $\%$ RSD & SEM & \multicolumn{2}{|c|}{$\begin{array}{c}\text { * Measured } \\
\text { Concentration }(\mu \mathrm{g} / \\
\mathrm{ml}) \pm \mathrm{SD}\end{array}$} & $\%$ RSD & SEM \\
\hline 10 & \multicolumn{2}{|r|}{$9.99 \pm 0.03$} & 0.03 & 0.0015 & \multicolumn{2}{|c|}{$9.75 \pm 0.04$} & 0.02 & 0.0012 \\
\hline 20 & \multicolumn{2}{|r|}{$19.97 \pm 0.02$} & 0.02 & 0.0021 & \multicolumn{2}{|c|}{$19.98 \pm 0.13$} & 0.67 & 0.0768 \\
\hline 50 & \multicolumn{2}{|r|}{$50.07 \pm 0.07$} & 0.15 & 0.0424 & \multicolumn{2}{|c|}{$49.72 \pm 0.26$} & 0.53 & 0.1513 \\
\hline \multicolumn{9}{|c|}{ Accuracy } \\
\hline \multicolumn{2}{|c|}{ Spiked Concentration $(\mu \mathrm{g} / \mathrm{ml})$} & \multicolumn{2}{|c|}{$\begin{array}{c}\text { Total Concentration }(\mu \mathrm{g} / \\
\mathrm{ml})\end{array}$} & \multicolumn{2}{|c|}{$\begin{array}{c}\text { * Concentration Found } \\
(\mu \mathrm{g} / \mathrm{ml}) \pm \text { SD }\end{array}$} & $\%$ RSD & SEM & \%Recovery \\
\hline \multicolumn{2}{|l|}{$16(80 \%)$} & \multicolumn{2}{|l|}{36} & \multicolumn{2}{|c|}{$35.61 \pm 0.0568$} & 0.16 & 0.0911 & 98.91 \\
\hline \multicolumn{2}{|l|}{$20(100 \%)$} & \multicolumn{2}{|l|}{40} & \multicolumn{2}{|c|}{$39.64 \pm 0.0210$} & 0.05 & 0.0303 & 99.11 \\
\hline \multicolumn{2}{|l|}{$24(120 \%)$} & \multicolumn{2}{|l|}{44} & \multicolumn{2}{|c|}{$43.82 \pm 0.2109$} & 0.48 & 0.2767 & 99.59 \\
\hline
\end{tabular}

*Mean of three replicates

The robustness of the method was estimated by assaying the sample in diverse analytical conditions by deliberately making slight fluctuations the original condition. From the results (Table 4), it was shown that the system suitability parameters, retention times and the assays for the test solution was not much affected there by signifying that the method is robust.

\section{Stress degradation studies}

The stability-indicating capability of the method was established from the separation of PTB peak from the degradation peaks of degraded samples. Figure 5 has shown the evidence of chromatograms of the stressed samples. PTB shows sufficient degradation in acidic and alkaline stress conditions, which resulted in the formation of degradant peaks at 3.207, 4.288 and $4.578 \mathrm{~min}$ in acid degradation and at 4.602 and 5.492 min during alkaline degradation. The drug peak was separated properly with better resolution from the so formed degradants, for which the system suitability parameters were within the acceptance criteria as shown in Table 5 . The 3D chromatograms for the degradation studies were obtained from the PDA data which shows the selectivity of the wavelength and the degradation peaks at the wide range of wavelength (Figure $4 \mathrm{a}-4 \mathrm{~g}$ ). During the optimization of the conditions for oxidative stress 


\begin{tabular}{|c|c|c|c|c|c|c|}
\hline Parameter (condition) & *\%Assay \pm SD & \%RSD & SEM & ${ }^{*}$ Retention time \pm SD & \%RSD & SEM \\
\hline \multicolumn{7}{|c|}{ Mobile phase flow rate $( \pm 10 \%)$} \\
\hline$(0.54 \mathrm{ml} / \mathrm{min})$ & $100.00 \pm 0.0121$ & 0.01 & 0.0070 & $5.19 \pm 0.0154$ & 0.2965 & 0.0089 \\
\hline$(0.66 \mathrm{ml} / \mathrm{min})$ & $99.02 \pm 1.6933$ & 1.71 & 0.9776 & $4.89 \pm 0.0172$ & 0.3521 & 0.0099 \\
\hline \multicolumn{7}{|c|}{ Detection wavelength $( \pm 2 \mathrm{~nm})$} \\
\hline$(217 \mathrm{~nm})$ & $98.03 \pm 1.6902$ & 1.72 & 0.9758 & $5.21 \pm 0.0065$ & 0.1248 & 0.0038 \\
\hline$(221 \mathrm{~nm})$ & $99.85 \pm 0.0364$ & 0.04 & 0.0210 & $5.20 \pm 0.0036$ & 0.0693 & 0.0021 \\
\hline \multicolumn{7}{|c|}{ Mobile phase composition ( $0.1 \%$ TFA: Acetonitrile) $( \pm 2, v / v)$} \\
\hline$(12: 88, v / v)$ & $99.99 \pm 0.0099$ & 0.01 & 0.0057 & $5.22 \pm 0.0316$ & 0.6042 & 0.0182 \\
\hline$(08: 92, v / v)$ & $99.81 \pm 0.0634$ & 0.06 & 0.0366 & $5.20 \pm 0.0032$ & 0.0619 & 0.0019 \\
\hline
\end{tabular}

*Mean of three replicates

\begin{tabular}{|c|c|c|c|c|c|c|c|}
\hline Stress Conditions & $\begin{array}{c}\text { Retention } \\
\text { time }\left(R_{t}\right)\end{array}$ & $\begin{array}{c}{ }^{*} \text { Drug } \\
\text { recovered (\%) }\end{array}$ & $\begin{array}{c}{ }^{*} \text { Drug } \\
\text { decomposed } \\
(\%) \\
\end{array}$ & $\begin{array}{c}\text { Theoretical } \\
\text { plates (N) }\end{array}$ & $\begin{array}{l}\text { Tailing } \\
\text { factor }\end{array}$ & Extra peaks & $\begin{array}{l}\text { Resolution } \\
\text { (R) }\end{array}$ \\
\hline Standard & 5.178 & 100.00 & 0.00 & 15342.694 & 1.269 & - & - \\
\hline \multirow[t]{3}{*}{ Acidic degradation } & \multirow[t]{3}{*}{5.154} & \multirow[t]{3}{*}{92.35} & \multirow[t]{3}{*}{7.65} & \multirow[t]{3}{*}{15453.164} & \multirow[t]{3}{*}{1.278} & 3.207 & \multirow[t]{3}{*}{3.497} \\
\hline & & & & & & 4.228 & \\
\hline & & & & & & 4.578 & \\
\hline \multirow[t]{2}{*}{ Alkaline degradation } & \multirow[t]{2}{*}{5.171} & \multirow[t]{2}{*}{95.43} & \multirow[t]{2}{*}{4.57} & \multirow[t]{2}{*}{14508.194} & \multirow[t]{2}{*}{1.273} & 4.602 & \multirow[t]{2}{*}{2.797} \\
\hline & & & & & & 5.492 & \\
\hline Oxidative degradation & 5.175 & 93.01 & 6.99 & 15602.304 & 1.274 & - & - \\
\hline Thermal degradation & 5.203 & 97.21 & 2.79 & 14911.933 & 1.279 & - & - \\
\hline Hydrolysis & 5.137 & 99.13 & 0.87 & 14323.968 & 1.261 & - & - \\
\hline Photolytic degradation & 5.123 & 96.37 & 3.63 & 14912.366 & 1.266 & - & - \\
\hline
\end{tabular}

*Mean of three replicates

\begin{tabular}{|c|c|c|c|}
\hline \multicolumn{4}{|c|}{ Table 6: Assay of Available Formulations. } \\
\hline Formulation & $\begin{array}{c}\text { Labelled claim } \\
\text { (mg) }\end{array}$ & $\begin{array}{c}\text { Amount } \\
\text { found }^{*}(\mathbf{m g})\end{array}$ & $\begin{array}{c}\% \\
\text { Recovery }^{*}\end{array}$ \\
\hline I & 50 & 49.38 & 98.75 \\
\hline II & 50 & 49.37 & 98.94 \\
\hline
\end{tabular}

degradation study, the strength of the Hydrogen peroxide was varied for 3\% Hydrogen peroxide and finally to $30 \%$ Hydrogen peroxide. Even at the final condition the drug have shown almost no degradation. As mentioned in the ICH Q1B Guidelines, ${ }^{20}$ for photo-stability forced degradation studies, a variety of exposure conditions may be used, depending on the photo sensitivity of the drug. It is appropriate to limit the exposure and end the study if extensive degradation occurs. But in our case, the dug has almost shown no degradation even exposed for 7 days.

\section{Analysis of commercial formulations}

The proposed method was applied to the assay of available formulations for the determination of PTB. The \% recovery was found to be 98.75-98.94 (Table 6).
The resultant chromatograms obtained for the assay of marketed formulations were shown in Figure 3c-3d.

\section{CONCLUSION}

The proposed stability-indicating HPLC method for the determination of PTB in pharmaceutical dosage forms was developed and validated as per ICH guidelines. The water used in this method development is of HPLC grade and was procured from Merck (India). The method has produced precise results during the interday precision studies which was conducted in 3 different days, which implies that the water quality shows no effect in the method development.. From the forced degradation studies it was clear that PTB was tends to be more sensitive towards acidic and alkaline degradations. The drug peak was sufficiently resoluted for the 


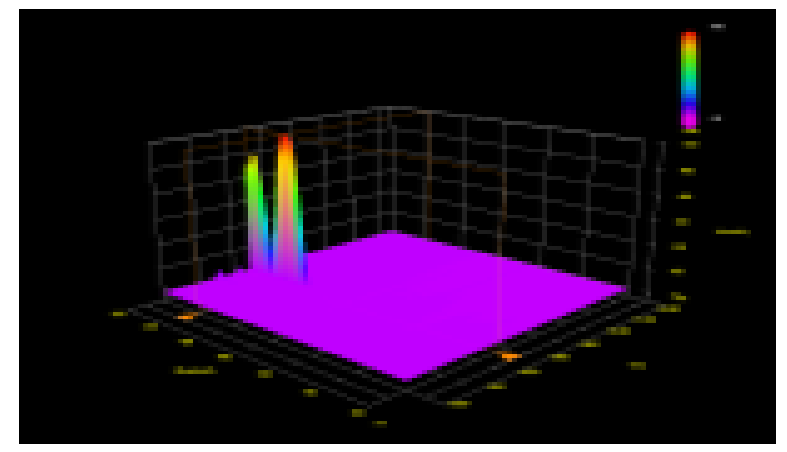

(a)

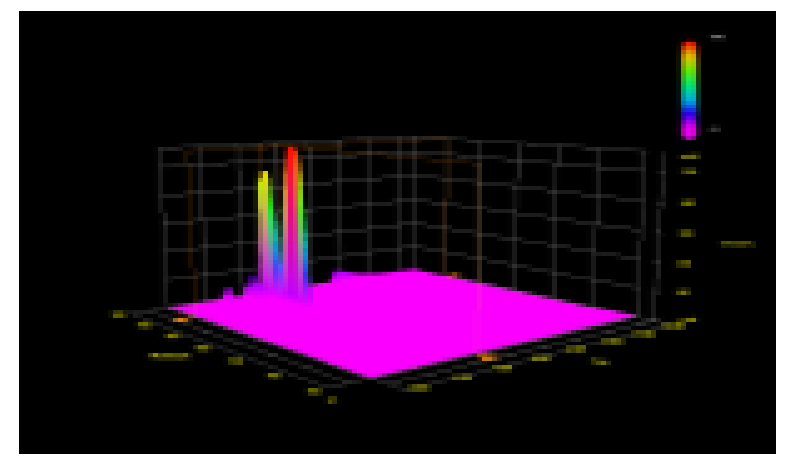

6

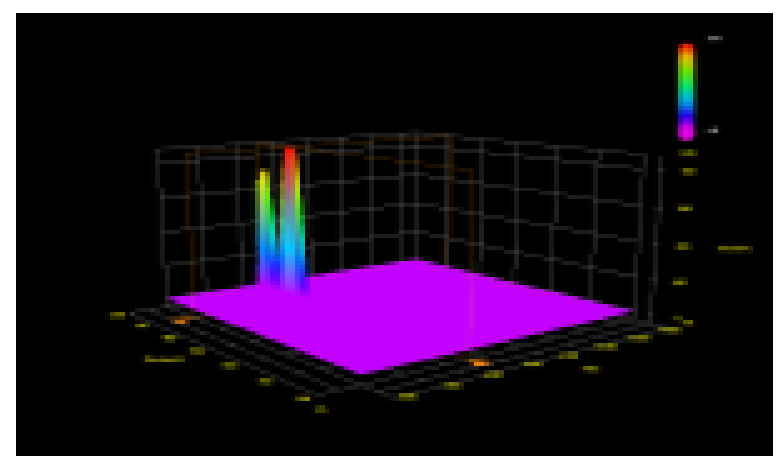

(6)

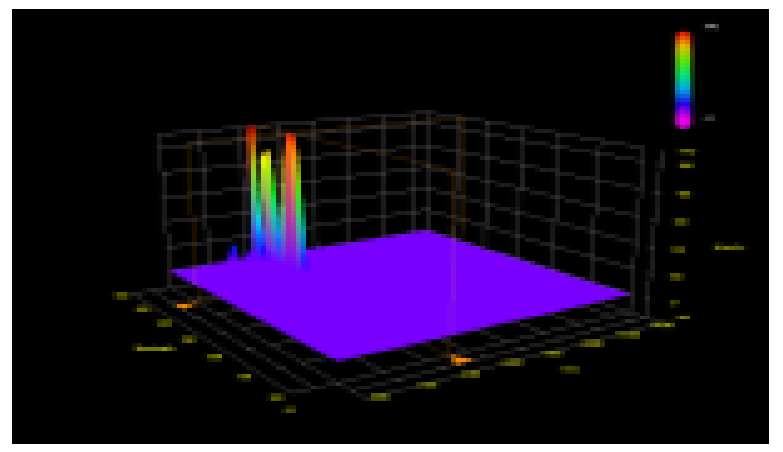

(b)

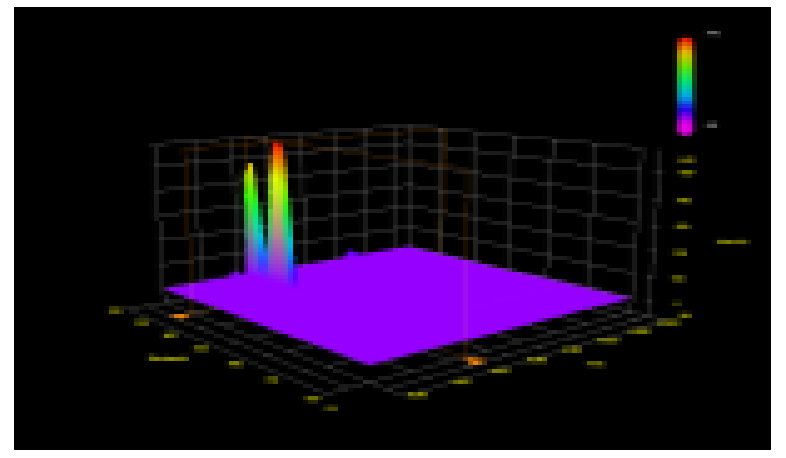

(1)

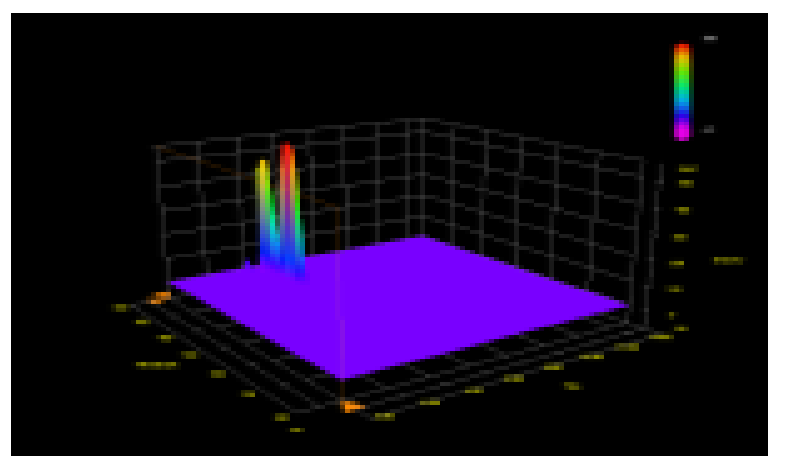

(f)

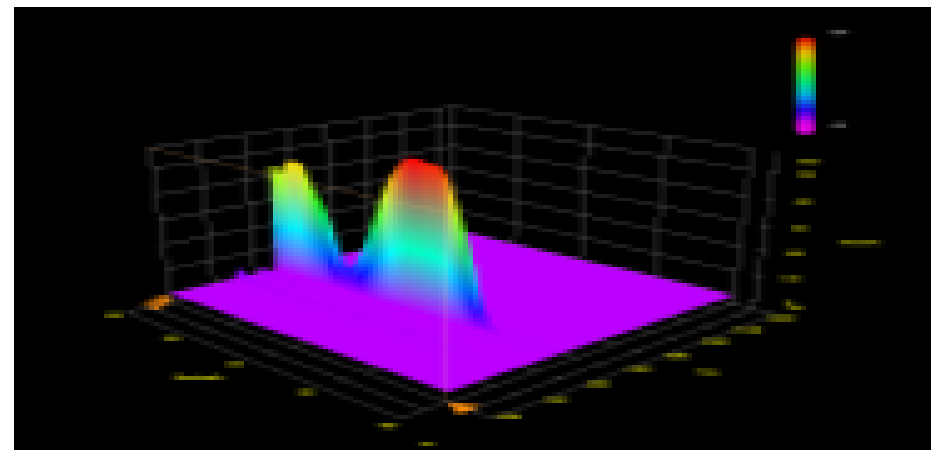

(3)

Figure 4: 3D Chromatograms of Pterostilbene (a) Standard (20 $\mu \mathrm{g} / \mathrm{ml})$ (b) Alkaline (c) Acidic (d) Oxidative (e) Photolytic (f) Thermal and $(g)$ Hydrolysis degradations 


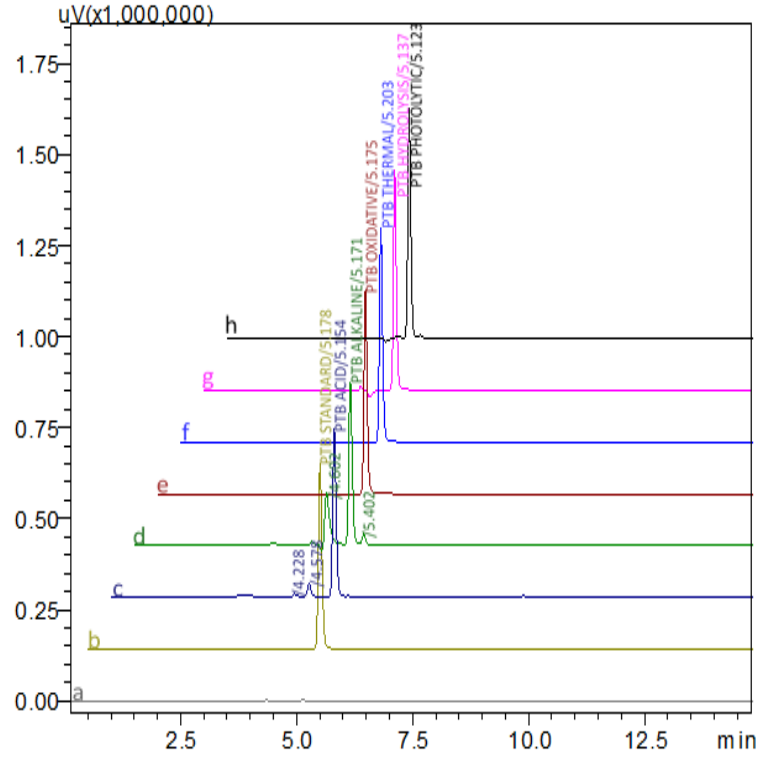

Figure 5: Typical chromatograms of Pterostilbene (a) Blank (b) Standard (20 $\mu \mathrm{g} / \mathrm{ml})$ (c) Acidic (d) Alkaline (e) Oxidative (f) Thermal (g) Hydrolysis (h) Photolytic degradations

so formed degradants obtained during stress degradation studies. The developed method was successfully applied to the available formulations. This method can be helpful for the long term stability studies and also to the kinetics studies.

\section{ACKNOWLEDGEMENT}

The authors are grateful to University Grants Commission, New Delhi, India for the financial support and $\mathrm{M} / \mathrm{s}$ GITAM (Autonomous) (Deemed to be University) Visakhapatnam for providing research facilities. The authors are very much thankful M/s Symed labs for providing the gift samples of Pterostilbene and there is no conflict of interest..

\section{CONFLICT OF INTEREST}

Authors decalare no conflict of interest.

\section{ABBREVIATIONS}

PTB: Pterostilbene; RP:HPLC: Reverse Phase High Performance Liquid Chromatography; TFA: Trifluoroacetic acid; ACN: Acetonitrile; $\mathbf{N a O H}$ : Sodium hydroxide; HCl: Hydrochloric acid; H2O2: Hydrogen peroxide; ICH: International Conference on Harmonization; RSD: Relative Standard Deviation; LOQ: Limit of Quantitation; LOD: Limit of Detection

\section{REFERENCES}

1. Seshadri TR. Polyphenols of Pterocarpus and Dalbergia woods. Phytochemistry. 1972;11(3):881-98.

2. Fuendjiep V, Wandji J, Tillequin F, Mulholland DA, Budzikiewicz H, Fomum ZT, et al. Chalconoid and stilbenoid glycosides from Guibourtia tessmanii. Phytochemistry. 2002;60(8):803-6.

3. Pezet R, Pont V. Identification of pterostilbene in grape berries of Vitis vinifera. Plant Physiol. Biochem. 1988;26(5):603-7.

4. Adrian M, Jeandet P, Douillet-Breuil AC, Tesson L, Bessis R. Stilbene content of mature Vitis vinifera berries in response to UV-C elicitation. J. Agric. Food Chem. 2000;48(12):6103-5.

5. Breuil ACD, Jeandet P, Adrian M, Bessis R. Changes in the phytoalexin content of various Vitis spp. in response to ultraviolet $C$ elicitation. J. Agric. Food Chem. 1999;47(10):4456-61.

6. Manickam M, Ramanathan M, Jahromi MAF, Chansouria JPN, Ray AB. Antihyperglycemic activity of phenolics from Pterocarpus marsupium. J. Nat. Prod. 1997;60(6):609-10.

7. Rimando AM, Cuendet M, Desmarchelier C, Mehta RG, Pezzuto JM, and Duke SO. Cancer chemopreventive and antioxidant activities of pterostilbene, a naturally occurring analogue of resveratrol. J. Agric. Food Chem. 2002;50(12):3453-7.

8. Roberti M, Pizzirani D, Simoni D, Rondanin R, Baruchello R, Bonora C, et al. Synthesis and biological evaluation of resveratrol and analogues as apoptosis-inducing agents. J. Med. Chem. 2003;46(16):3546-54.

9. Tolomeo M, Grimaudo S, Cristina AD, Roberti M, Pizzirani D, Meli M, et al. Pterostilbene and 3'-Hydroxypterostilbene are effective apoptosis-inducing agents in MDR and BCR-ABL-expressing leukemia cells. Int. J. Biochem. Cell Biol. 2005;37(8):1709-26.

10. Ferrer P, Asensi M, Segarra R, Ortega A, Beniloch M, Obrador E, et al. Association between pterostilbene and quercetin inhibits metastatic activity of B16 melanoma. Neoplasia. 2005;7(1):37-47.

11. Stivala LA, Savio M, Carafoli F, Perucca P, Bianchi L, Maga G, et al. Specific structural determinants are responsible for the antioxidant activity and the cell cycle effects of resveratrol. J. Biol. Chem. 2001;276(25):22586-94.

12. Akansha M, Rohit S, Swayam PS, Sudeep G, Rakesh M, Akhilesh KT, et al. Confirmation towards establishing antidiabetic activity in heart wood of Pterocarpus marsupium and analysis of phytoconstituents. Indian J. Exp. Biol. 2013;51:363-74.

13. Amorati R, Lucarini M, Mugnaini V, Pedulli GF. Antioxidant activity of hydroxystilbene derivatives in homogeneous solution. J. Org. Chem. 2004;69(21):7101-7.

14. Jeandet P, Douillet-Breuil AC, Bessis R, Debord S, Sbaghi M, Adrian M. Phytoalexins from the Vitaceae: Biosynthesis, phytoalexin gene expression in transgenic plants, antifungal activity, and metabolism. J. Agric. Food Chem. 2002;50(10):2731-41.

15. Connie MR, Jaime AY, Kathryn AR, Neal MD. High-performance liquid chromatographic analysis of pterostilbene in biological fluids using fluorescence detection. J. Pharm. Biomed. Anal. 2007;43(1):250-4.

16. Lin HS, Yue BD, Ho PC. Determination of pterostilbene in rat plasma by a simple HPLC-UV method and its application in pre-clinical pharmacokinetic study. Biomed. Chromatogr. 2009;23(12):1308-15.

17. Mathrusri Annapurna M, Sai Phani Kumar J. New derivative and differential spectrophotometric methods for the determination of pterostilbene - an antioxidant. Pharm. Methods. 2015;6:143-7.

18. ICH: Validation of analytical procedures. Text and methodology Q2 (R1), International Conference on Harmonization. 2005.

19. ICH: Stability testing of new drug substances and products Q1A (R2), International Conference on Harmonization. 2003.

20. 20. $\mathrm{ICH}$ : Stability testing: Photo-stability testing of new drug substances and products Q1B, International Conference on Harmonization, 1996.. 
PICTORIAL ABSTRACT

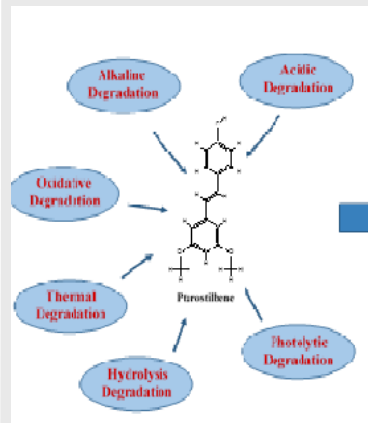

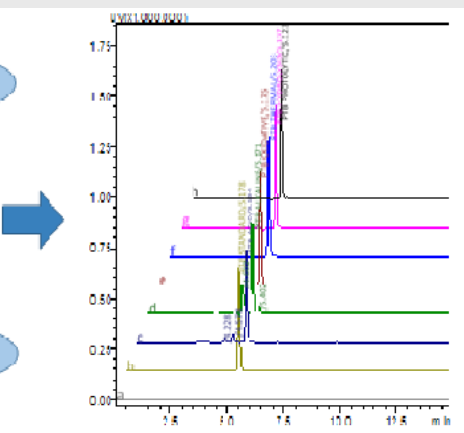

\section{SUMMARY}

- Pterostilbene is a stilbenoid, with diversified pharmacological activities such as anti-oxidant, antiinflammatory, anti-diabetic, anti-cancer etc.

- A new stability-indicating RP-HPLC method has been developed and validated (ICH guidelines) for the determination of Pterostilbene.

- Optimized chromatographic conditions -

- Mobile Phase: Trifluoroacetic acid in water: Acetonitrile $(10: 90 \%, v / v)$

- Flow rate: $0.6 \mathrm{ml} / \mathrm{min}$ (UV detection at $219 \mathrm{~nm}$ ).

\section{About Authors}

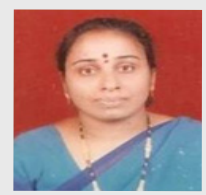

Prof. Mukthinuthalapati Mathrusri Annapurna is working at GITAM Institute of Pharmacy, GITAM (Deemed to be University), Visakhapatnam, India. She pursued her B. Pharm (1990) and M. Pharm (1993) from Andhra University, Visakhapatnam and Ph.D from Berhampur University, Orissa. Her research is keenly focussed on analytical method development, validation and degradation studies of drug molecules. She also explores computer augmented simulated studies of metal complexes of drug molecules.

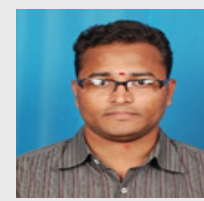

Mr. Bukkapatnam Venkatesh: Obtained his M.Pharm (2013) and currently pursuing Ph.D. (Pharmaceutical Analysis) (JRF-UGC) at GITAM Institute of Pharmacy, GITAM (Deemed to be University), Visakhapatnam, India.

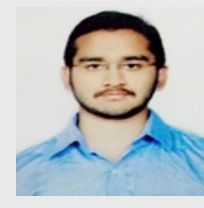

Mr. Gunnam Ravi Teja: Currently pursuing M. Pharmacy (Pharmaceutical Analysis) (2016-2018) at GITAM Institute of Pharmacy, GITAM (Deemed to be University), Visakhapatnam, India.

Cite this article: Annapurna MM, Venkatesh B, Teja GR. Development of a Validated Stability Indicating Liquid Chromatographic Method for the Determination of Pterostilbene. Indian $\mathrm{J}$ of Pharmaceutical Education and Research. 2018;52(4S):S63-S70. 